\title{
Exposure as Collected Lot Number
}

National Cancer Institute

\section{Source}

National Cancer Institute. Exposure as Collected Lot Number. NCI Thesaurus. Code C117487.

A distinctive alpha-numeric identification code assigned by the manufacturer or distributor to a specific quantity of manufactured material or product within a batch that the subject was exposed to. 